\title{
A story of cutaneous pearls: asymptomatic plaques and nodules on buttocks associated with cutaneous calcinosis
}

\section{Blaszki i guzki na pośladkach związane z wapnicą skóry}

Vishalakshi S. Pandit, Vijayakumara Adavi

Department of Dermatology, Venereology and Leprosy, Koppal Institute of Medical Sciences, Koppal, India

Zakład Dermatologii, Wenerologii i Trądu, Instytut Medycyny w Koppal, Indie

Dermatol Rev/Przegl Dermatol 2018, 105, 548-553 DOI: https://doi.org//0.5 I |4/dr.2018.78076

\author{
CORRESPODNING AUTHOR/ \\ ADRES DO KORESPONDENCJI: \\ Vishalakshi S. Pandit MD \\ Department of Dermatology, \\ Venereology and Leprosy \\ Koppal Institute \\ of Medical Sciences \\ \#303, 'C' Staff Quarters \\ KIMS Campus \\ Gangavati Road \\ 583231 Koppal, India \\ Phone: +91 9844381033 \\ E-mail: vishalaxisp@gmail.com
}

\begin{abstract}
Introduction. Calcinosis cutis is a rare disorder characterized by an aberrant calcium deposition in the skin and subcutaneous tissue. Clinical manifestations vary from localized papules and nodules to debilitating lesions that can involve large areas of the body. Idiopathic calcinosis cutis is the rarest subtype.
\end{abstract}

Objective. To present a rare morphological form of idiopathic calcinosis cutis on the right side of the buttocks occurring in an uncommon age.

Case report. A 62-year-old woman presented with asymptomatic plaques and nodules on the buttocks for the past 3 years. She had a history of repeated whitish discharge from the lesions. The cutaneous examination showed ill-defined, hyperpigmented plaques, studded with white-coloured nodules and papules. Her laboratory investigations such complete haemogram, liver function tests, renal function tests, serum electrolytes, calcium $(9.2 \mathrm{mg} / \mathrm{dl})$ and phosphorus $(3 \mathrm{mg} / \mathrm{dl})$ levels were within the normal limits. The histopathological examination of the biopsied tissue showed basophilic calcium deposits extruding through the epidermal layers. The von Kossa stain showed black deposits.

Conclusions. Idiopathic calcinosis cutis is a skin calcification with no known aetiology and an unclear pathogenesis. Idiopathic calcinosis cutis of the buttocks is very rare in old age. Differentiation of idiopathic calcinosis cutis from other causes of soft tissue calcifications, nocardiosis and parasitic infestations is essential. Knowledge of this benign condition can prevent unnecessary diagnostic tests and aggressive medical treatment.

\section{STRESZCZENIE}

Wprowadzenie. Wapnica skóry jest rzadką chorobą charakteryzującą się występowaniem złogów wapnia w skórze i tkance podskórnej. Objawy kliniczne to miejscowe grudki i guzki, ale zdarzają się także wyniszczające zmiany obejmujące znaczną powierzchnię ciała. Idiopatyczna wapnica skóry to najrzadszy podtyp choroby.

Cel pracy. Przedstawienie rzadkiej morfologicznie postaci idiopatycznej wapnicy skóry po prawej stronie pośladków, która wystąpiła w nietypowym wieku.

Opis przypadku. Kobieta 62-letnia z bezobjawowymi blaszkami i guzkami na pośladkach występującymi od 3 lat. $W$ wywiadzie podawała 
często pojawiającą się białawą wydzielinę ze zmian. W badaniu skóry wykazano nieostro odgraniczone przebarwione blaszki z białymi guzkami i grudkami. Wyniki badań laboratoryjnych, takich jak morfologia, próby czynnościowe wątroby, czynność nerek, elektrolity w surowicy, w tym stężenie wapnia $(9,2 \mathrm{mg} / \mathrm{dl})$ i fosforu $(3 \mathrm{mg} / \mathrm{dl})$, były w normie. $\mathrm{W}$ badaniu histopatologicznym stwierdzono zasadochłonne zwapnienia skóry przebijające się przez naskórek. Barwienie metodą von Kossa wykazało czarne złogi.

Wnioski. Idiopatyczna wapnica skóry jest chorobą o nieznanej etiologii i patogenezie. Idiopatyczna wapnica skóry pośladków jest niezwykle rzadka w podeszłym wieku. Bardzo ważne jest odróżnienie idiopatycznej wapnicy skóry od innych przyczyn wapnienia tkanek miękkich, nokardiozy oraz zakażeń pasożytniczych. Swiadomość występowania tej łagodnej choroby pozwala uniknąć nadmiernej diagnostyki i intensywnego leczenia.

Key words: deposits, calcinosis, plaques.

Słowa kluczowe: złogi, wapnica, blaszki.

\section{INTRODUCTION}

Calcinosis cutis is a rare disorder characterized by an amorphous calcium deposition in the skin and subcutaneous tissue. Clinical manifestations vary from localized papules, nodules and plaques to debilitating lesions that can involve large areas of the skin [1]. It can be classified as: dystrophic, metastatic, iatrogenic and idiopathic. Idiopathic calcinosis cutis usually occurs in the first or second decade of life. Idiopathic calcinosis cutis of the buttocks is a very rare clinical entity. It has to be evaluated to rule out calcinosis occurring as a part of collagen disorders like systemic lupus erythematosus, dermatomyositis and inherited pseudoxanthoma elasticum [2].

\section{OBJECTIVE}

The aim of the study was to present a rare morphological form of idiopathic calcinosis cutis on the right side of the buttocks occurring in an uncommon age.

\section{CASE REPORT}

A 62-year-old female presented with asymptomatic plaques and nodules on the right side of the buttocks for the past 3 years. The growth of the lesion was slow with minimal increase in the number since their first appearance. No previous history of trauma or injection at the site of the lesion. She had a histo-

\section{WPROWADZENIE}

Wapnica skóry to rzadka choroba charakteryzująca się występowaniem amorficznych złogów wapnia w skórze i tkance podskórnej. Objawy kliniczne obejmują grudki, guzki i blaszki, a nawet wyniszczające zmiany zajmujące duże obszary skóry [1]. Wapnica może zostać zaklasyfikowana jako: dystroficzna, przerzutowa, jatrogenna i idiopatyczna. Idiopatyczna wapnica skóry występuje zazwyczaj w pierwszej lub drugiej dekadzie życia. Idiopatyczna wapnica skóry pośladków to niezwykle rzadka jednostka chorobowa. W diagnostyce różnicowej należy wykluczyć wapnicę współwystępującą z chorobami tkanki łącznej, takimi jak toczeń rumieniowaty układowy, zapalenie skórno-mięśniowe i pseudoxanthoma elasticum [2].

\section{CEL PRACY}

Przedstawienie rzadkiej postaci idiopatycznej wapnicy skóry zlokalizowanej po prawej stronie pośladków, która wystąpiła w nietypowym wieku.

\section{OPIS PRZYPADKU}

Kobieta 62-letnia z bezobjawowymi blaszkami i guzkami występującymi po prawej stronie pośladków od 3 lat. Zmiany rozwijały się wolno, a ich liczba wzrosła nieznacznie od momentu pojawienia się. W wywiadzie nie stwierdzono urazów lub iniekcji w miejscu zmiany. W czasie ostatnich 6 miesięcy często pojawiała się biaława 
ry of repeated whitish discharge from the lesions for last 6 months. There was no history of photosensitivity, muscular weakness, joint pain or joint immobility. There was no remarkable event in her past history. The cutaneous examination showed ill-defined, non-tender, hyperpigmented to skin-coloured plaques, studded with white-coloured, firm to hard papules and nodules on the right side of the buttocks (fig. 1). A few of the nodules show a milky-white discharge. The rest of the physical and systemic examination revealed no abnormalities. The laboratory investigations like complete blood count with erythrocyte sedimentation rate were within normal limits. Liver and kidney function tests, blood glucose levels, serum electrolytes, uric acid, calcium $(9.2 \mathrm{mg} / \mathrm{dl})$ and phosphorus (3 mg/dl) levels were normal. A skin biopsy was done and the histopathological examination showed basophilic calcium deposits in the dermis and a few extruding through the epidermal layers (fig. 2). There was neither fibrotic tissue nor inflammation surrounding the calcium. This was confirmed by special staining with the von Kossa stain which revealed black deposits in the dermis (fig. 3). On the basis of clinical, biochemical and histopathological reports, diagnosis of idiopathic calcinosis cutis was made.

\section{DISCUSSION}

Calcinosis cutis is a condition in which insoluble calcium salts are deposited in the skin and subcutaneous tissue. Based on the aetiology, calcinosis cutis can be classified into 5 variants: dystrophic (calcium deposited in damaged or degenerate tissue with normal calcium and phosphate levels), metastatic (elevated serum levels of calcium or phosphate), idiopathic (unknown etiopathogenesis), iatrogenic (resulting wydzielina ze zmian. W wywiadzie pacjentka negowała nadwrażliwość na światło, osłabienie mięśni, dolegliwości bólowe i zaburzenia ruchomości stawów. Dotychczasowy wywiad bez znaczących odchyleń. W badaniu skóry stwierdzono po prawej stronie pośladków nieostro odgraniczone, niebolesne blaszki, przebarwione lub w kolorze skóry, z białymi, twardymi guzkami i grudkami (ryc. 1). Z kilku guzków wydobywała się mlecznobiała wydzielina. Nie stwierdzono innnych odchyleń w badaniu przedmiotowym. Wyniki badań laboratoryjnych, takich jak morfologia z OB, były w normie. Badania czynności wątroby i nerek, stężenie glukozy we krwi, elektrolity w surowicy, kwas moczowy, stężenie wapnia $(9,2 \mathrm{mg} / \mathrm{dl})$ i fosforu (3 mg/dl) były w normie. Wykonano wycinek skóry, a w badaniu histopatologicznym stwierdzono zasadochłonne złogi wapnia w skórze właściwej, niektóre z nich przebijały się przez warstwę naskórka (ryc. 2). Wapń nie był otoczony przez tkanki włókniste lub zmiany zapalne. Zostało to potwierdzone w barwieniu metodą van Kossa, które wykazało czarne złogi w skórze właściwej (ryc. 3). Na podstawie wyników badań klinicznych, biochemicznych i histopatologicznych rozpoznano idiopatyczną wapnicę skóry.

\section{OMÓWIENIE}

Wapnica skóry to choroba, w której nierozpuszczalne sole wapnia odkładają się w skórze i tkance podskórnej. Ze względu na etiologię wapnica skóry może zostać zaklasyfikowana jako: dystroficzna (złogi wapnia w uszkodzonej tkance przy stężeniu wapnia i fosforanów w normie), przerzutowa (podwyższone stężenie wapnia lub fosforanów), jatrogenna (wywołana przez działania niepożądane leczenia)

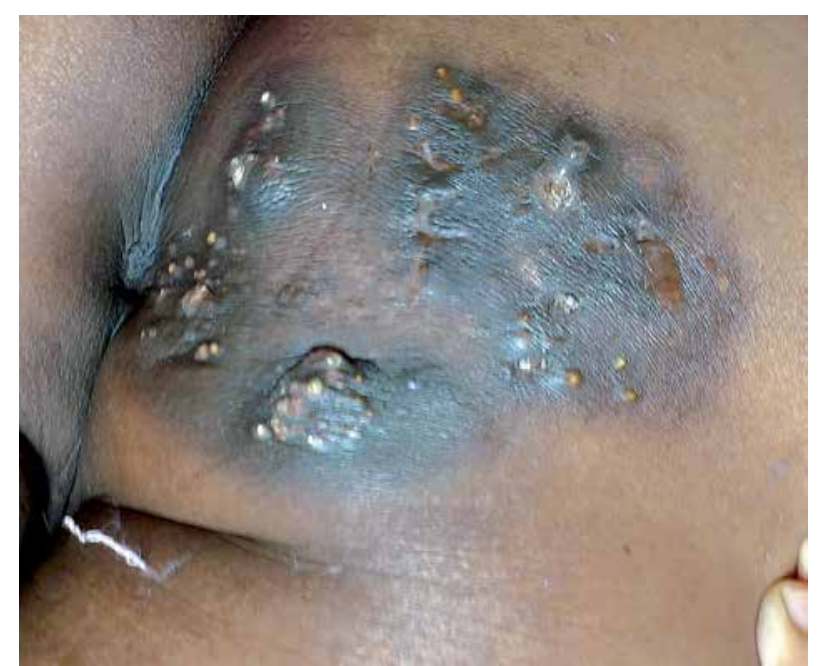

Figure I. III-defined, skin-coloured to hyperpigmented plaques studded with papules and nodules on the buttocks Rycina I. Nieostro odgraniczone blaszki na pośladkach, przebarwione lub w kolorze skóry, z guzkami i grudkami 


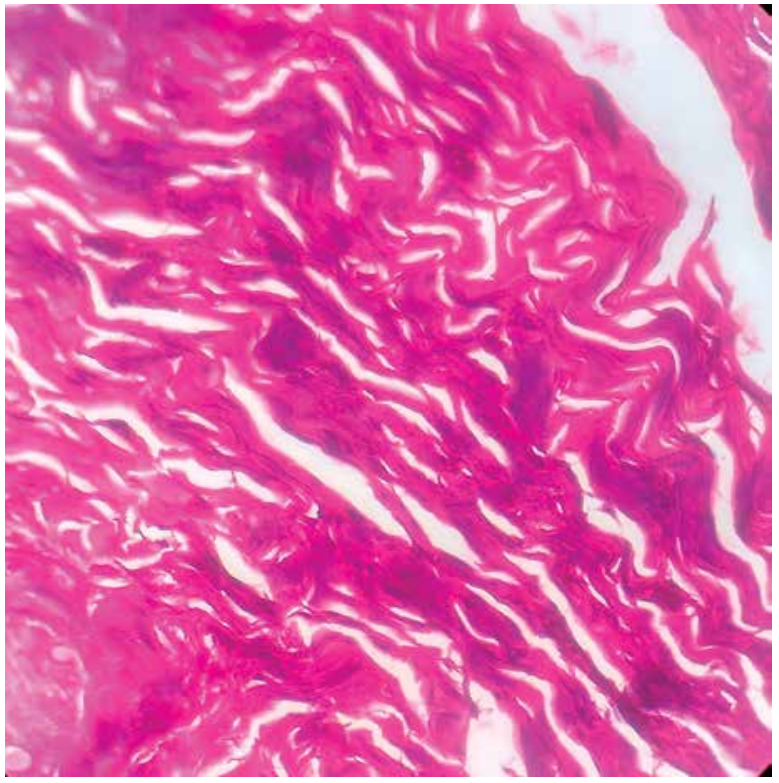

Figure 2. High power view showing basophilic calcium deposits extruding through epidermal layers $(H+E, 40 \times)$

Rycina 2. Obraz w dużym powiększeniu przedstawiający zasadochłonne złogi wapnia przechodzące przez warstwy naskórka $(H+E$, $40 \times)$

from a therapy-associated side effect) and calciphylaxis (calcification of the small vessels in the dermis and subcutaneous fat) [1].

The term idiopathic calcification is reserved for skin calcification that is associated with neither any underlying tissue injury nor a systemic disorder. Idiopathic calcinosis cutis is the rarest subtype. Only a small number of cases of idiopathic calcinosis cutis have been reported in early childhood or adolescence [3]. Idiopathic calcinosis cutis is subclassified into: (a) tumoural calcinosis, characterized by masses around major joints mainly appearing in otherwise healthy adolescents; (b) sub-epidermal calcified nodules occurring on the head and extremities, the disorder usually being seen in children and (c) scrotal calcinosis [1].

The common sites for idiopathic calcinosis cutis are the scalp, extremities, joints and genitalia. The presentation of idiopathic calcinosis cutis as large subcutaneous nodules and plaques in old age is unusual as idiopathic calcinosis cutis presents commonly as solitary, hard, white-yellowish, sub-epidermal papules of 3-11 mm on the scalp, extremities and scrotum. The onset of the occurrence of the mass may be in childhood or adulthood. This type of nodular idiopathic calcinosis cutis was also seen in the infrapatellar region in an athlete who is a marathon runner, which suggests that the occurrence of calcinosis cutis may be related with chronic repeated physical activity [4].

Histopathology of the tissue shows calcium deposits by their intense, uniform basophilia. The initial

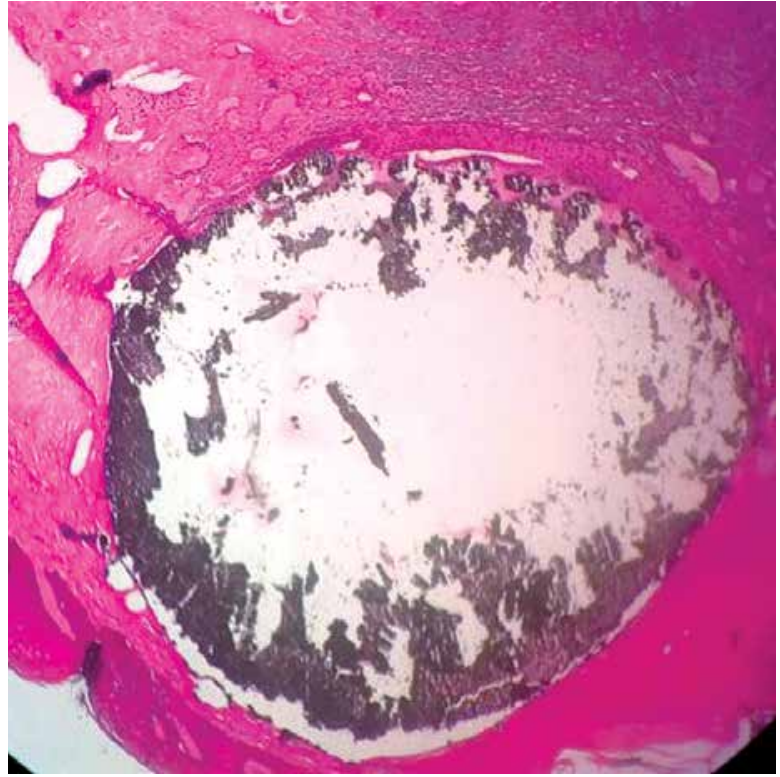

Figure 3. Von Kossa stains showing black calcium deposits in the dermis

Rycina 3. Barwienie metodą von Kossa - czarne złogi wapnia w skórze właściwej

i kalcyfilaksja (zwapnienia małych naczyń krwionośnych w skórze właściwej i w tkance tłuszczowej) [1].

Termin zwapnienie idiopatyczne jest zarezerwowany dla zwapnienia skóry niezwiązanego z urazem tkanki ani zaburzeniami ogólnoustrojowymi. Idiopatyczna wapnica skóry to najrzadziej występujący podtyp. Jedynie niewielka liczba przypadków idiopatycznej wapnicy skóry została stwierdzona we wczesnym dzieciństwie lub okresie dojrzewania [3]. Idiopatyczna wapnica skóry jest klasyfikowana jako następujące podtypy: a) wapnica nowotworowa, charakteryzująca się guzami wokół większych stawów występującymi u zdrowych dotąd nastolatków; b) podnaskórkowe zwapniałe guzki na głowie i kończynach, występujące głównie u dzieci i c) kalcynoza moszny [1].

Idiopatyczna wapnica skóry często występuje na głowie, kończynach, stawach i w okolicach narządów płciowych. Objawy w postaci dużych podskórnych guzków i blaszek u starszych osób są nietypowe, gdyż idiopatyczna wapnica skóry zazwyczaj ma postać odrębnych, twardych, biało-żółtawych, podnaskórkowych grudek o rozmiarach 3-11 mm na skórze głowy, kończyn i moszny. Choroba może mieć początek w dzieciństwie lub wieku dojrzałym. Ten typ guzkowatej idiopatycznej wapnicy skóry obserwowano również w okolicy podrzepkowej u maratończyka, co oznacza, że wapnica skóry może być związana z aktywnością fizyczną o charakterze ciągłym i powtarzalnym [4].

W badaniu histopatologicznym tkanki stwierdzono złogi wapnia w postaci intensywnych, jednako- 
phase is characterized by oedema, collagen degeneration, mucin deposits, and hyalinization with necrosis and cyst formation. Foci of calcium deposition are large and dense, which can be confirmed by von Kossa's silver stain which blackens the deposits.

The chemical composition can also be evaluated by vibrational micro-spectroscopy in which type $B$ carbonated apatite and $\beta$-carotene are seen interspersing sub-cutaneous tissue present in idiopathic calcinosis cutis [5].

There are two distinct phases of the disease: an active and an inactive phase, which can coexist in the same lesion. In the active phase or cellular phase, the calcified amorphous material, contained inside cystic spaces, appears surrounded by a proliferation of histiocytes giant cells and long-term inflammatory elements. In the inactive phase, it shows only calcified material, surrounded by a dense ipo-cellular fibrous tissue that extends to adjacent structures.

Differential diagnosis includes nocardiosis, $\mathrm{cu}$ taneous tuberculosis and other types of soft tissue calcifications such as metastatic calcification (calcification due to hyper- or hypoparathyroidism, paraneoplastic hypercalcaemia), dystrophic calcifications in inherited disorders (Ehlers-Danlos or pseudoxanthoma elasticum), soft tissue tumour, gout or parasitic infections [2].

Idiopathic calcinosis cutis is difficult to treat as the pharmacological agents are not generally accepted as a standard line of treatment to prevent or reduce calcinoisis. Randomized controlled trials are not available to guide the management of this rare condition. Warfarin, colchicine, probenecid, bisphosphonates and diltiazem have been tried with varying degrees of success. Curettage or surgical excision is the first-line therapy for idiopathic calcinosis cutis though electrodessication or $\mathrm{CO}_{2}$ laser ablation may be performed for small, multiple lesions. Newer modalities of treatment include intralesional steroids, antitumour necrosis factor, intravenous immunoglobulins and extracorporeal shockwave lithotripsy [1].

\section{CONCLUSIONS}

Idiopathic calcinosis cutis is the rarest subtype of calcinosis cutis and occurs usually in early childhood or adolescence. On the basis of the presented case of a 62-year-old female, a rare morphological form occurring on the buttocks and - what needs to be emphasized - presenting in old age is described. The condition needs to be differentiated from other conditions presenting as discharging nodules and/or asymptomatic plaques such as nocardiosis, lupus vulgaris and other soft tissue calcifications. Knowledge wych wybarwień zasadochłonnych. Faza początkowa charakteryzuje się obrzękiem, degeneracją kolagenu, złogami mucyny, a także hialinizacją połączoną z martwicą i tworzeniem się torbieli. Ogniska złogów wapnia są duże i zbite, co można potwierdzić w barwieniu srebrem metodą von Kossa, które zabarwia na czarno złogi.

Skład chemiczny można ocenić w spektroskopii wibracyjnej, w której węglan apatytu typu B i $\beta$-karoten przeplatają tkankę podskórną [5].

Choroba przebiega w dwóch wyraźnych fazach: aktywnej i nieaktywnej, które mogą współistnieć w obrębie tej samej zmiany. W fazie aktywnej, inaczej komórkowej, zwapniały, amorficzny materiał znajdujący się w torbielowatych przestrzeniach jest otoczony przez proliferujące olbrzymie histiocyty i komórki przewlekłego nacieku zapalnego. W nieaktywnej fazie widać jedynie zwapniały materiał otoczony przez zbitą, ubogokomórkową tkankę łączną włóknistą, która rozciąga się na przylegające struktury.

Rozpoznanie różnicowe obejmuje nokardiozę, gruźlicę skóry i inne rodzaje zwapnienia tkanek miękkich, takie jak wapnienie przerzutowe (wapnienie spowodowane nadczynnością lub niedoczynnością przytarczyc, paranowotworowa hiperkalcemia), dystroficzne wapnienie $\mathrm{w}$ zaburzeniach dziedzicznych (zespół Ehlersa-Danlosa lub zespół Grönblada-Strandberga), nowotwory tkanek miękkich, dna moczanowa lub infekcje pasożytnicze [2].

Leczenie idiopatycznej wapnicy skóry jest trudne, poniewaź środki farmakologiczne nie są powszechnie akceptowane jako standardowy wybór w zapobieganiu lub redukcji wapnicy. Randomizowane badania kontrolowane nie są dostępne w określeniu postępowania przy tej rzadkiej chorobie. Warfaryna, kolchicyna, probenecyd, bisfosfoniany i diltiazem były stosowane $\mathrm{z}$ różnym powodzeniem. Leczeniem pierwszego wyboru w idiopatycznej wapnicy skóry jest łyżeczkowanie lub wycięcie chirurgiczne, a w przypadku małych, licznych zmian skórnych można zastosować wypalanie jednobiegunowym prądem elektrycznym lub laserem ablacyjnym $\mathrm{CO}_{2}$. Nowsze metody obejmują glikokortykosteroidy podawane doogniskowo, leki blokujacce czynnik martwicy nowotworu, dożylne immunoglobuliny oraz pozaustrojowe kruszenie kamieni falami generowanymi pozaustrojowo [1].

\section{WNIOSKI}

Idiopatyczna wapnica jest najrzadziej występującym podtypem wapnicy skóry i pojawia się zazwyczaj we wczesnym dzieciństwie lub okresie dojrzewania. Na podstawie opisu przypadku 62-letniej pacjentki przedstawiono rzadką morfologicznie postać choroby obserwowana na pośladkach i co szcze- 
of this benign condition can prevent unnecessary diagnostic tests and aggressive medical treatment.

\section{CONFLICT OF INTEREST}

The authors declare no conflict of interest. gólnie należy podkreślić, u osób w starszym wieku. Idiopatyczną wapnicę skóry należy odróżnić od innych chorób, których objawami są guzki z wydzieliną i/lub bezbolesne blaszki, takich jak nokardioza, gruźlica toczniowa i inne zwapnienia tkanek miękkich. Świadomość występowania tej łagodnej choroby może zapobiec przeprowadzaniu zbędnych testów diagnostycznych i wdrażaniu agresywnego leczenia.

\section{KONFLIKT INTERESÓW}

Autorzy nie zgłaszają konfliktu interesów.

\section{References}

\section{Piśmiennictwo}

1. Reiter N., El-Shabrawi L., Leinweber B., Berghold A., Aberer E.: Calcinosis cutis: part I. Diagnostic pathway. J Am Acad Dermatol 2011, 65, 1-12.

2. Chauhan N.S., Sharma Y.P.: A child with skin nodules and extensive soft tissue calcification. Br J Radiol 2012, 85, 193-195

3. Cohen P.R., Tschen J.A: Idiopathic calcinosis cutis of the penis. J Clin Aesthet Dermatol 2012, 5, 23-30.

4. Valdatta L., Buoro M., Thione A., Mortarino C., Tuinder S., Fidanza C., et al.: Idiopathic circumscripta calcinosis cutis of the knee. Dermatol Surg 2003, 29, 1222-1224.

5. Niu D.M., Lin S.Y., Li M.J., Cheng W.T., Pan C.C., Lin C.C.: Idiopathic calcinosis cutis in a child: chemical composition of the calcified deposits. Dermatology 2011, 222, 201-205.

Received: 22.12 .2017

Accepted: 22.07.2018

Otrzymano: 22.12.2017 r.

Zaakceptowano: $22.07 .2018 \mathrm{r}$.

How to cite this article

Pandit V.S., Adavi V.: A story of cutaneous pearls: asymptomatic plaques and nodules on buttocks associated with cutaneous calcinosis. Dermatol Rev/Przegl Dermatol 2018, 105, 548-553. DOI: https://doi.org/10.5114/dr.2018.78076. 